\title{
HUBUNGAN KEBIASAAN BERMAIN GAME ONLINE DENGAN KUALITAS TIDUR REMAJA PADA KELAS XI DI SMKN 1 SERUYAN TENGAH
}

\author{
${ }^{1}$ Alem Habibi, ${ }^{2}$ Wahyudi Qorahman MM, ${ }^{3}$ Rastia Ningsih,,${ }^{4}$ Rukmini Syahleman, \\ ${ }_{1,2,3,4}$ STIKes Borneo Cendekia Medika \\ E-mail Korespondensi : alemhabibi14@gmail.com
}

\begin{abstract}
ABSTRAK
Perkembangan teknologi komunikasi dan informasi pada saat ini internet tidak hanya digunakan untuk memenuhi kebutuhan informasi namun juga hal-hal yang bersifat hiburan (entertainment), salah satu hiburan internet adalah game. Game online merupakan permainan yang berbasis elektronik dan visual dapat dimainkan oleh banyak pemain dalam satu waktu yang memanfaatkan jaringan internet sebagai medianya. Bermain game online secara berlebihan dapat mengakibatkan kurangnya waktu tidur, pola tidur yang dapat berakibat pada terganggunya kesehatan. Fenomena game online juga dapat menyebabkan remaja menjadi kecanduan. Tujuan penelitian ini adalah mengetahui hubungan kebiasaan bermain game online dengan kualitas tidur remaja pada kelas XI di SMKN 1 Seruyan Tengah.

Desain dalam penelitian ini adalah Cross-Sectional. Populasi seluruh remaja kelas XI di SMKN 1 Seruyan Tengah adalah 55 orang. Teknik pengambilan sampel menggunakan total sampling. Instrumen penelitian menggunakan lembar angket dengan pengolahan data editing, coding, scoring, tabulasi, dan analisis data menggunakan uji korelasi rank spearman.

Hasil penelitian terhadap 55 responden yang terbiasa bermain game online selalu $27(49,1 \%)$, dan hampir semua responden dengan kualitas tidur buruk sebanyak 36 $(65,5 \%)$. Berdasarkan uji statistik rank Spearman ditemukan bahwa angka signifikan atau nilai probabilitas $(0,000)$ jauh lebih rendah dari signifikansi standar 0,05 atau ( $<$ < a). H1 diterima, artinya di SMKN 1 Seruyan Tengah ada hubungan antara kebiasaan bermain game online dengan kualitas tidur remaja pada kelas XI di SMKN 1 Seruyan Tengah.
\end{abstract}

Kata kunci : bermain, remaja, game online, kualitas tidur

\begin{abstract}
The development of communication and information technology at this time the internet is not only used to meet information needs but also things that are entertainment (entertainmen), one of the internet entertainment is games. Online games are electronic and visual-based games that can be played by many players at one time using the internet as the medium. Playing online games excessively results in a lack of sleep, a sleep pattern that can result in health problems. The phenomenon of online gaming can also cause teenagers to become addicted. The purpose of this study was to determine
\end{abstract}


the relationship between the habit of playing online games and the quality of sleep of adolescents in class XI at SMKN 1 Seruyan Tengah.

The design in this study was Cross Sectional analytic. The population of all class XI adolescents at SMKN 1 Seruyan Tengah totaled 55 people. The sampling technique uses total sampling. The research instrument used a questionnaire sheet with data processing editing, coding, scoring, tabulating and data analysis using the Spearman rank correlation test.

The results of the study of 55 respondents with the habit of playing online games with the criteria always being 27 people (49.1\%) and almost all respondents with poor sleep quality were 36 people $(65.5 \%)$. Based on the Spearman rank statistical test, it was found that the significant number or probability value $(0.000)$ was much lower than the standard significance of 0.05 or $(\mathrm{p}<\mathrm{a})$. H1 is accepted which means that there is a relationship between the habit of playing online games and the quality of sleep of adolescents in class XI at SMKN 1 Seruyan Tengah.

Keywords : play, teenagers, online games, sleep quality

\section{PENDAHULUAN}

\section{Latar Belakang}

Dengan berkembangnya teknologi komunikasi dan informasi, peralatan teknis saat ini tidak hanya perlu memiliki satu fungsi, tetapi juga perlu memiliki banyak fungsi sekaligus untuk memenuhi kebutuhan manusia. Tuntutan perangkat dengan banyak fungsi mendorong kreativitas manusia untuk mengembangkan fungsi ini di masa depan. Saat ini internet tidak hanya digunakan untuk memenuhi kebutuhan informasi, tetapi juga untuk menghibur (menghibur) berbagai hal. Game merupakan salah satu hiburan internet yang telah menarik perhatian masyarakat luas. Di masa lalu, hanya Internet yang dapat memainkan game secara offline, dan kemunculan game internet memungkinkan mereka untuk bermain game online tanpa lebih banyak waktu. Game online saat ini dikembangkan oleh perkembangan dan kemajuan teknologi itu sendiri (Afriano dalam Febriana, 2012). Game online dapat disebut sebagai bagian dari aktivitas sosial karena pemain dapat berinteraksi secara virtual dan sering kali membuat komunitas virtual. Dalam hal ini semakin menunjukkan bagaimana interaksi dalam permainan tersebut mempengaruhi perkembangan pemain itu sendiri (Fauziawati, 2015).

Masa remaja merupakan masa kemudaan manusia. Pada masa remaja, manusia tidak bisa disebut dewasa, tetapi tidak bisa disebut anak-anak. Masa remaja adalah masa peralihan manusia dari masa kanak-kanak hingga dewasa. Masa remaja adalah masa 
transisi dari masa kanak-kanak hingga dewasa, dengan rentang usia antara 11 hingga 21 tahun. Menurut ilmu psikologi, masa remaja merupakan masa transisi dari masa kanak-kanak hingga dewasa, memasuki usia sekitar 10 hingga 12 tahun, dan berakhir pada usia 18 hingga 22 tahun. Perubahan fisik menyebabkan remaja mulai berpikir lebih tentang diri sendiri (Surbakti, 2017).

Bermain game online secara berlebihan mengakibatkan kurangnya tidur yang berakibat pada terganggunya kesehatan (Ridoi, 2018). Hal tersebut dapat terjadi karena seseorang yang sudah mengalami kecanduan akan merelakan waktu tidurnya hanya untuk bermain game online. Sebagai makhluk hidup, istirahat/tidur menjadi kebutuhan dasar yang harus terpenuhi. Tidur merupakan proses fisiologis yang sangat penting untuk kebutuhan fisiologis tubuh manusia. Seseorang tidak dapat bertahan hidup tanpa kualitas dan kuantitas tidur yang cukup, karena pada saat tidur sel-sel tubuh akan pulih, sehingga mengembalikan tubuh ke keadaan semula. Gangguan tidur yang sering dialami manusia antara lain insomnia, sleep apnea, dan insomnia (Krisna, 2016).
Kualitas tidur merupakan keadaan tidur yang dialami seseorang, yang akan menghasilkan rasa segar dan sehat setelah terbangun (Khasanah, 2012). Salah satu aspek utama dalam meningkatkan kesehatan adalah tetap tidur untuk memastikan bahwa fungsi tubuh dipulihkan ke tingkat fungsional terbaik, dan untuk memastikan bahwa mereka selalu waspada sepanjang hari untuk menyelesaikan tugas dan menikmati hidup yang berkualitas tinggi. Saat seseorang tidur di malam hari, otak akan mengintegrasikan pengetahuan baru dan membentuk asosiasi baru, sehingga membuat pikiran lebih segar. Penting bagi siswa untuk melakukan tidur di malam hari, agar saat siang hari siswa dapat mengikuti pembelajaran dengan baik selama di sekolah (Baert, et al., 2015).

Berdasarkan hasil studi pendahuluan pada remaja kelas XI di SMKN 1 Seruyan Tengah diketahui ada 55 pengguna aktif game online remaja usia 16-18 tahun dengan rata-rata penggunaan lebih dari 1 jam per hari. Hasil komunikasi terhadap 4 orang siswa, keempatnya mengungkapkan bahwa mereka bermain game online setiap hari dengan didukung oleh jaringan yang saat ini sudah bagus dan 
lancar. Mereka juga merasa ngantuk saat pelajaran berlangsung namun beberapa anak yang diwawancarai mengungkapkan dengan bermain game online mereka lebih berkonsentrasi dalam proses belajar dan dengan bermain game online mereka dapat menghilangkan kepenatan dalam belajar.

Berdasarkan data di atas, peneliti tertarik untuk melakukan penelitian tentang "Hubungan Kebiasaan Barmain Game Online dengan Kualitas Tidur Remaja pada Kelas XI di SMKN 1 Seruyan Tengah".

\section{Tujuan}

Untuk mengetahui hubungan, mengidentifikasi kebiasaan bermain game online, mengidentifikasi kualitas tidur, dan menganalisis hubungan kebiasaan bermain game online dengan kualitas tidur pada remaja kelas XI di SMKN 1 Seruyan Tengah.

\section{Manfaat}

Hasil penelitian dapat memberikan pemahaman kepada responden tentang pentingnya mengatur waktu bermain game online, memberikan wawasan tentang pengaruh kebiasaan bermain game online, memberikan informasi dasar atau tambahan bagi peneliti selanjutnya.

\section{Tinjauan Pustaka}

Permainan adalah kegiatan di mana remaja dapat mengekspresikan ide-idenya, berkreasi, dan mempersiapkan diri untuk berperan dan berperilaku seperti orang dewasa. Bermain merupakan kegiatan yang memberikan keterampilan, pembelajaran dan perkembangan yang efektif (Aziz dalam Roije, 2016).

Permainan online adalah permainan internet yang disediakan oleh pengembang permainan berupa aplikasi permainan atau diinstal pada browser atau server tertentu. Gunakan komputer, konsol game, atau ponsel untuk bermain game online, dan beberapa pemain yang terhubung ke internet dapat memainkan game tersebut bersama-sama. Secara garis besar terdapat tiga kategori utama dari game online yaitu Basic Online Games, Multiplayer Games, dan MMOG (Massively Multiplayer Online Games). Sedangkan tergantung dari jenis keseruannya, game online dibedakan menjadi adventure, simulasi dan RPG, serta game alternative reality (Harumi dalam Astuti, 2018). 
Tidur merupakan kebutuhan dasar yang dibutuhkan pada setiap orang. Istirahat dan tidur yang cukup harus cukup agar tubuh dapat berfungsi secara normal. Selama istirahat dan tidur, tubuh melakukan proses pemulihan untuk mengembalikan daya tahan tubuh dan menjadikannya dalam kondisi terbaik (Guyton \& Hall dalam Putri et al., 2017).

Masa remaja sering disebut sebagai tahap perkembangan transisi, yang membawa individu dari masa kanak-kanak hingga dewasa. Dalam proses adaptasi menuju masa dewasa, remaja harus melalui beberapa tahapan (Agustina dalam Astuti, 2018).

\section{METODE PENELITIAN}

Dalam penelitian ini, peneliti menggunakan metode analisis deskriptif dan metode Cross-Sectional untuk mengukur atau mempelajari variabel independen dan data variabel dependen hanya satu kali. Peneliti menggunakan desain Cross-Sectional karena bermaksud menggunakan alat ukur angket untuk mengetahui ada tidaknya hubungan antara variabel independen dengan variabel dependen dalam suatu pengukuran (Nursalam, 2017).

\section{Populasi, Sampel, dan Teknik Pengambilan Sampel}

Populasi penelitian ini adalah seluruh siswa XI SMKN 1 Seruyan Tengah XI 2020 yang berjumlah 55 orang. Sampel penelitian ini berjumlah 55 orang. Dalam pengambilan sampel menggunakan teknik total sampling yaitu teknik pengambilan sampel untuk pengambilan sampel seluruh anggota populasi (Sugiyono, 2018).

\section{Pengumpulan Data dan Pengolahan Data}

Alat penelitian adalah alat pengumpul data yang dirancang untuk memperoleh data yang sesuai (data kualitatif atau kuantitatif) untuk disusun (Nursalam, 2013). Pengumpulan data menggunakan lembar kuesioner. Dalam pengolahan data terdapat beberapa tahapan yaitu editing, scoring, coding, tabulation.

\section{Operasional Variabel}

Variabel independent adalah variabel yang nilainya menentukan yang lain (variabel dependent). Variabel independen biasanya dimanipulasi, diamati dan diukur untuk mengetahui hubungan atau pengaruhnya terhadap variabel lain (Nursalam, 2017). Dalam 
penelitian ini variabel bebasnya adalah kebiasaan bermain game online.

Variabel dependent merupakan variabel yang nilainya ditentukan oleh variabel lain. Variabel terikat merupakan faktor observasi dan pengukuran yang digunakan untuk mengetahui apakah variabel independent mempunyai hubungan atau pengaruh (Nursalam, 2017). Dalam penelitian ini variabel terikatnya adalah kualitas tidur remaja.

\section{Analisa Univariat}

Analisis univariat adalah analisis setiap variabel berdasarkan hasil penelitian, biasanya analisis ini hanya menggambarkan sebaran dan persentase masing-masing variabel, tanpa sampai pada kesimpulan yang digeneralisasikan (Ghozali, 2011).

Untuk mengetahui kebiasaan bermain game online, gunakan rumus analisis (Hidayat, 2014) sebagai berikut: $p=\frac{f}{N} \times 100$

\section{Keterangan :}

$\mathrm{p}=$ Nilai yang didapat

$\mathrm{f}=$ Skor yang didapat

$\mathrm{N}=$ Skor maksimal
Kriteria :

Selalu (76-100\%)

Jarang (26-75\%)

Tidak pernah $(<26 \%)$

Sedangkan untuk mengetahui kualitas tidur yaitu menggunakan Pittsburgh Sleep Quality Index (PQSI) dengan kriteria baik skor $<5$ dan buruk skor > 5 (Robins dalam Fadlilah, 2020).

\section{Analisa Bivariat}

Analisis bivariat merupakan analisis yang dilakukan terhadap dua variabel yang diduga berhubungan atau berkorelasi yang dilakukan dengan pengujian statistik (Notoatmodjo, 2010). Untuk mengetahui apakah terdapat hubungan signifikan antara dua variabel atau tidak dengan kemaknaan 0,05 dengan menggunakan uji korelasi dengan software SPSS 21. Pada penelitian ini menggunakan uji spearman rank yaitu data berskala ordinal, dimana $p<0,05$ maka ada hubungan kebiasaan bermain game online dengan kualitas tidur remaja pada kelas XI di SMKN 1 Seruyan Tengah, apabila $p>0,05$ tidak ada hubungan kebiasaan bermain game online dengan kualitas tidur remaja pada kelas XI di SMKN 1 Seruyan Tengah. 


\section{HASIL DAN PEMBAHASAN}

\section{Gambaran Umum Tempat Penelitian}

Penelitian dan pengambilan data dilakukan di SMKN 1 Seruyan Tengah yang berada di Jalan Garuda Desa Suka Maju Sukamandang B-1 Kecamatan Seruyan Tengah Kabupaten Seruyan Provinsi Kalimantan Tengah. SMKN 1 Seruyan Tengah merupakan satusatunya SMK yang ada di Sukamandang yang memiliki 2 jurusan yaitu ATP (Agribisnis Tanaman Perkebunan) dan APHP (Agribisnis Pengolahan Hasil Pertanian). Posisi SMKN 1 Seruyan Tengah sebelah Timur berbatasan dengan Desa Sukorejo Sukamandang G-1, sebelah Barat berbatasan dengan Desa Suka Makmur Sukamandang B-2, sebelah Selatan berbatasan langsung dengan Perkebunan Sawit Jaya Desa Suka Maju Sukamandang B-1, dan sebelah Utara berbatasan dengan Desa Batu Agung Sukamandang B-3.

\section{Hasil}

Tabel 1. Distribusi frekuensi responden berdasarkan umur, jenis kelamin, informasi dan sumber informasi pada kelas XI di SMKN 1 Seruyan Tengah

\begin{tabular}{lcc}
\hline Karakteristik & Frekuensi & $\%$ \\
\hline Umur & & \\
Remaja Awal & 0 & 0,0 \\
Remaja Pertengahan & 55 & 100,0
\end{tabular}

\begin{tabular}{|c|c|c|}
\hline Remaja Akhir & 0 & 0 \\
\hline Karakteristik & Frekuensi & $\%$ \\
\hline \multicolumn{3}{|l|}{ Jenis Kelamin } \\
\hline Laki-Laki & 35 & 63,6 \\
\hline Perempuan & 20 & 36,4 \\
\hline \multicolumn{3}{|l|}{ Informasi } \\
\hline Pernah & 50 & 90,9 \\
\hline Tidak Pernah & 5 & 9,1 \\
\hline \multicolumn{3}{|l|}{ Sumber Informasi } \\
\hline Petugas Kesehatan & 4 & 7,3 \\
\hline Majalah & 0 & 0,0 \\
\hline Televisi/Radio & 10 & 18,2 \\
\hline Internet & 41 & 74,5 \\
\hline Total & 55 & 100,0 \\
\hline
\end{tabular}

Sumber : Data Primer

Berdasarkan tabel 1 menunjukkan bahwa seluruhnya responden dengan usia remaja pertengahan sejumlah 55 orang $(100,0 \%)$. Kemudian sebagian besar responden dengan jenis kelamin laki-laki sejumlah 35 orang $(63,6 \%)$. Setelah itu, sebagian besar responden pernah mendapatkan informasi sejumlah 50 orang $(90,9 \%)$ dan sebagian besar responden mendapatkan sumber informasi dari internet sejumlah 41 orang $(74,5 \%)$.

Tabel 2. Kategori responden berdasarkan kebiasaan bermain game online pada kelas XI di SMKN 1 Seruyan Tengah

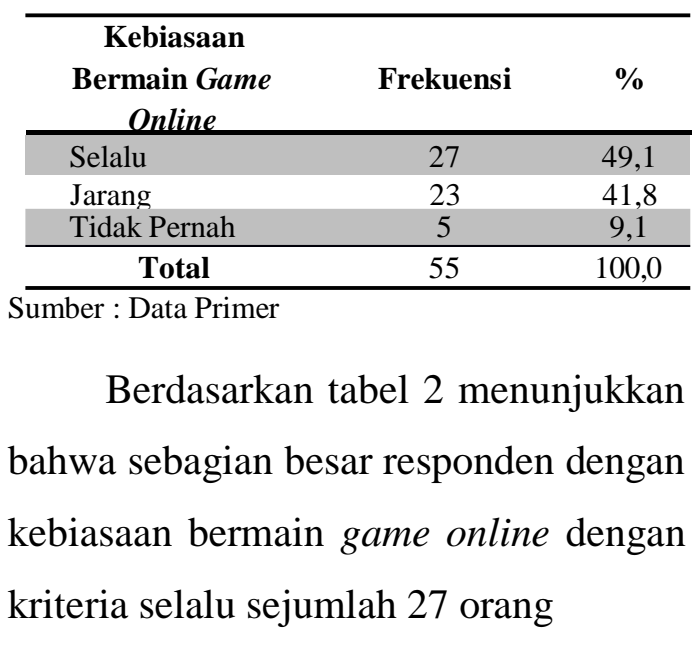


$(49,1 \%)$ dan sebagian kecil responden dengan kebiasaan bermain game online dengan kriteria tidak pernah sejumlah 5 orang $(9,1 \%)$.

Tabel 3. Kategori responden berdasarkan kualitas tidur remaja pada kelas XI di SMKN 1 Seruyan Tengah

\begin{tabular}{ccc}
\hline $\begin{array}{c}\text { Kualitas Tidur } \\
\text { Remaja }\end{array}$ & Frekuensi & \% \\
\hline Buruk & 36 & 65,5 \\
Baik & 19 & 34,5 \\
\hline Total & 55 & 100,0 \\
\hline Sumber : Data Primer & &
\end{tabular}

Berdasarkan tabel 3 menunjukkan bahwa sebagian besar responden berada dalam kualitas tidur buruk sejumlah 36 orang $(65,5 \%)$ dan sebagian kecil responden berada dalam kualitas tidur baik sejumlah 19 orang (34,5\%).

Tabel 4. Tabulasi silang hubungan kebiasaan bermain game online dengan kualitas tidur remaja pada kelas XI di SMKN 1Seruyan Tengah

\begin{tabular}{cccccccc}
\hline & \multicolumn{5}{c}{ Kualitas Tidur Remaja } \\
\cline { 2 - 7 } $\begin{array}{c}\text { Kebiasaan } \\
\text { bermain } \\
\text { game onlie }\end{array}$ & \multicolumn{2}{c}{ Buruk } & \multicolumn{2}{c}{ Baik } & \multicolumn{2}{c}{ Total } \\
\cline { 2 - 7 } & $\mathrm{N}$ & $\%$ & $\mathrm{~N}$ & $\%$ & $\mathrm{~N}$ & $\%$ \\
\hline Selalu & 24 & 88,9 & 3 & 11,1 & 27 & 100 \\
Jarang & 12 & 52,2 & 11 & 47,8 & 23 & 100 \\
Tidak & 0 & 0,0 & 5 & 100 & 5 & 100 \\
pernah & 36 & 65,5 & 19 & 34,5 & 55 & 100 \\
\hline Total & & & & & & & \\
\hline
\end{tabular}

Sumber : Data Primer

Berdasarkan tabel 4 menunjukkan bahwa dari 55 responden selalu terbiasa bermain game online mempengaruhi kualitas tidur remaja buruk sejumlah 36 orang $(65,5 \%)$.

Tabel 5. Korelasi hubungan kebiasaan bermain game online dengan kualitas tidur remaja pada kelas XI di SMKN 1 Seruyan Tengah

\begin{tabular}{cccc}
\hline \multicolumn{4}{c}{ Rank Spearman } \\
\hline Variabel & $\mathbf{N}$ & $\begin{array}{c}\text { Correlation } \\
\text { Coefficient }\end{array}$ & $\begin{array}{c}\boldsymbol{P} \\
\text { value }\end{array}$ \\
\hline $\begin{array}{c}\text { Game Online } \\
\text { Kualitas } \\
\text { Tidur }\end{array}$ & 55 & 1,000 &. \\
\hline Tidu & 55 &, $547^{*}$ &, 000 \\
\hline
\end{tabular}

Sumber : Data Primer

Berdasarkan tabel 5 menunjukkan bahwa nilai p value $(0,000)$ jauh lebih rendah dari standar signifikan dari 0,05 atau $(\mathrm{p}<\mathrm{q}) . \mathrm{H} 1$ diterima ygberarti ada hubungan kebiasaan bermain game online dengan kualitas tidur remaja pada kelas XI di SMKN 1 Seruyan Tengah.

\section{Pembahasan}

\section{Umur}

Remaja pertengahan ditandai dengan berkembangnya kemampuan berpikir yang baru, sehingga fenomena minat dan peran masyarakat untuk menjadi dewasa yang mandiri mulai terlihat (Agustina dalam Astuti, 2018). Dibandingkan dengan orang dewasa, remaja dianggap lebih umum dan lebih cenderung menjadi kecanduan game online. Masa remaja berada dalam keadaan tidak stabil yang mengarah pada kecenderungan untuk 
bereksperimen dan menjadi penasaran dengan hal-hal baru (Jordan dan Andersen, 2016).

Semakin tua usia seseorang, semakin tinggi pula kematangan pemikiran dan pekerjaan masyarakat. Sejauh menyangkut kepercayaan publik, usia terkait dengan tingkat persiapan seseorang, dan kepercayaan publik lebih dewasa daripada orang yang tidak cukup dewasa, dan akan memiliki lebih banyak kepercayaan. Ini adalah hasil dari pengalaman psikologis seseorang (Notoatmodjo, 2014).

Peneliti berpendapat bahwa ratarata, pada masa remaja, seorang siswa masih mencari kesenangan dan masih kurang memiliki rasa tanggung jawab yang kuat dalam pembelajaran di sekolah dan mencapai hasil yang diinginkan. Banyak anak remaja di era sekarang yang masih menggunakan fungsi smartphone untuk bermain game online, para siswa yang terusik dengan game online akan memanjakan diri dalam bermain game tanpa memikirkan belajar dan bertanggung jawab.

\section{Jenis Kelamin}

Remaja laki-laki menyukai game online karena memiliki berbagai tingkat kesulitan dan terdapat unsur kekerasan dalam game tersebut. Bahkan jika bermain di tempat yang berbeda mereka bisa bermain dengan teman, sedangkan wanita menyukai game yang dianggap berkarakteristik atau ekspresi diri yang lebih mudah untuk dimainkan. Rata-rata game online yang ada di pasaran saat ini adalah game online bertema kekerasan, sehingga lebih diminati oleh remaja pria (Febriandari et al., 2016).

Peneliti berpendapat bahwa remaja terutama pada laki-laki mengalami gangguan tidur dikarenakan remaja menghabiskan banyak waktu hanya untuk game online yang diminati. Remaja akan terus bermain untuk dapat menyelesaikan permainan atau sampai merasa puas. Hal tersebut dapat terjadi secara terus-menerus dikarenakan di dalam game online juga menyediakan layanan chat, bahkan ada yang bisa berkomunikasi dengan tim atau lawan bicara langsung melalui voice note.

\section{Informasi}

Remaja yang pernah mendapatkan informasi tentang game online akan membuat remaja semakin penasaran dan pada akhirnya tertarik untuk mencoba game online tersebut (Azizah, 2018). Sumber infomasi mejadikan remaja semakin penasaran terhadap game 
online. Game online adalah aktivitas yang menghabiskan waktu dan emosional yang dapat membuat remaja kecanduan game online. Remaja yang menjadi tanggungan akan menolak untuk tidur, makan, berolahraga, melakukan hal lain, dan bersosialisasi dengan orang lain (Young dalam Syahran, 2015).

Informasi dapat memengaruhi pengetahuan seseorang, meskipun tingkat pengetahuan seseorang rendah. Seseorang mendapatkan informasi yang baik dari berbagai media (seperti TV, radio atau koran), sehingga dapat menambah pengetahuan masyarakat (Notoatmodjo, 2014).

Peneliti berpendapat bahwa remaja yang pernah mendapatkan informasi tentang game online akan tertarik dan mencoba sehingga remaja cenderung semakin asyik untuk terus bermain game online. Remaja juga tidak menghiraukan akan dampak yang ditimbulkan jika terus menerus bermain game online yang dapat menganggu kualitas tidur.

\section{Sumber Informasi}

Salah satu kegiatan yang digunakan remaja untuk memanfaatkan internet adalah hiburan, seperti hiburan online, menonton audio, SMS (chat), mendengarkan (mendownload musik) dan bermain game. Menggunakan internet untuk bermain game online merupakan aktivitas yang menarik (Horigan dalam Kusumawati, 2017). Dengan pesatnya perkembangan teknologi internet, game online juga berkembang pesat. Game online didasarkan pada game elektronik dan visual. Game online dewasa ini sangat populer di berbagai kalangan, dan salah satunya sangat populer di kalangan remaja (Rini dalam Fithriyana, 2019).

Sumber informasi akan mempengaruhi pemahaman seseorang terhadap hal-hal tertentu, sehingga informasi yang diperoleh dapat terkumpul secara utuh. Dalam hal ini dapat menggunakan pengalaman pribadi untuk mendapatkan pengetahuan (Notoatmodjo, 2014).

Peneliti berpendapat bahwa di era sekarang remaja mendapatkan sumber informasi tentang game online sangatlah mudah seperti melalui internet. Remaja yang semakin penasaran terhadap game online akan terus mencari dan menghabiskan banyak waktu hanya untuk bermain game online.

Kebiasaan bermain game online 
Pemain memilih bermain game online disebabkan beberapa alasan yaitu mencari kesenangan, rekreasi, mengatasi stres, mendapatkan status atau pengakuan, dan melarikan diri dari kehidupan nyata (Vollmer dkk, 2014). Intensitas atau lamanya waktu bermain game online dapat mempengaruhi kecerdasan emosi remaja, faktor yang menyebabkan naiknya tingkatan bermain game online akan membuat remaja merasa penasaran untuk terus bermain di tingkatan yang lebih sulit dengan tantangan yang baru (Kholidiyah dan Yuwono, 2013). Dibandingkan dengan orang dewasa, remaja dianggap lebih sering dan lebih mudah menggunakan game online. Jika terlalu banyak bermain game online dapat berdampak negatif bagi remaja (Kusumadewi dalam Saputra, 2017).

Peneliti berpendapat bahwa bermain game online yang terlalu lama akan menjadikan remaja semakin penasaran dan akhirnya tertarik untuk mencoba game online sehingga para remaja cenderung semakin asyik untuk terus bermain game online. Game online ini sangatlah menarik karena dalam permainan tersebut seseorang tidak hanya bermain dengan orang yang berada disebelahnya, namun dapat bermain dengan beberapa pemain di lokasi lain sampai di seluruh dunia.

\section{Kualitas tidur remaja}

Kualitas tidur merupakan suatu kondisi. Dalam kondisi ini, tidur yang dialami individu akan menghasilkan rasa segar dan sehat pada saat terbangun sehingga membuat orang merasa kenyang dengan tidurnya, sehingga penderita tidak menunjukkan rasa lelah dan cemas. Kualitas tidur remaja buruk dikarenakan terlalu banyak bermain game online sehingga kurang tidur. Pemain yang tidak bisa mengatur waktu saat bermain game online sehingga mengakibatkan tidak teraturnya dan kurangnya waktu tidur yang dapat mempengaruhi pada kurangnya waktu tidur pada remaja (Khasanah \& Khusnul, 2012).

Apabila kepuasan tidur seseorang terpenuhi, maka kualitas tidur dianggap baik, sehingga seseorang tidak akan merasa lelah, mudah merasa gelisah, mengantuk, cuek, dan gelap di sekitar mata. Kelopak mata bengkak, bengkak konjungtiva, mata perih, perpecahan perhatian, sakit kepala dan sering terjadi penguapan (Hidayat dari Azizah, 2018).

Peneliti berpendapat bahwa remaja memiliki kualitas tidur buruk 
karena terlalu banyak menghabiskan waktu bermain game online, sehingga kurang tidur. Remaja masih belum bisa mengatur waktu bermain game online, menyebabkan waktu tidur yang tidak teratur dan mempengaruhi kurang tidur mereka.

\section{Analisis hubungan kebiasaan bermain game online dengan kualitas tidur remaja pada kelas XI}

Hasil uji statistik rank spearman diperoleh nilai probabilitas $(0,000)$ jauh lebih rendah dari standar signifikan dari 0,05 atau $(\mathrm{p}<\mathrm{Q})$. H1 diterima berai ada hubungan kebiasaan bermain game online dengan kualitas tidur remaja pada kelas XI di SMKN 1 Seruyan Tengah.

Menurut Azizah (2018), kualitas tidur yang buruk karena sebagian besar pemain bermain game online terus menerus setiap hari. Remaja selalu mengabaikan masalah yang akan ditimbulkan, dan tidak mau mengatur waktu belajar dan bermain game online, sehingga dampaknya sangat serius. Hal tersebut akan mempengaruhi kualitas tidur, mengakibatkan wajah pucat, mata lelah, dan kurang konsentrasi selama belajar sehingga berakibat pada penurunan prestasi akademik. Sementara menurut Young dalam
Azizah (2018), terlalu lama bermain game online merupakan salah satu faktor yang dapat mempengaruhi kebutuhan tidur remaja yang belum terpenuhi. Game online ini sangat menarik karena di dalam game ini seseorang tidak hanya bisa bermain dengan orang yang ada di sebelahnya, tetapi juga dengan beberapa pemain dari belahan dunia lain.

Berdasarkan uraian diatas dapat disimpulkan bahwa kebiasaan bermain game online dapat mempengaruhi kualitas tdur remaja. Sedangkan remaja yang terbiasa bermain game online masih menambah dan menghabiskan banyak waktunya hanya dengan bermain game online dan lupa istirahat atau tidur. Hal ini akan berdampak pada kesehatan mental, menurunnya daya tahan tubuh, menurunkan prestasi belajar, mudah tersinggung, depresi, kurang konsentrasi, dan kelelahan.

\section{KESIMPULAN DAN SARAN}

\section{Kesimpulan}

Berdasarkan hasil penelitian yang dilakukan peneliti didapatkan bahwa :

1. Kebiasaan bermain game online pada remaja kelas XI di SMKN 1 Seruyan Tengah menunjukkan bahwa 
sebagian besar responden memiliki kategori selalu bermain game online.

2. Kualitas tidur remaja pada kelas XI di SMKN 1 Seruyan Tengah menunjukkan bahwa sebagian besar responden masuk dalam kategori buruk.

3. Ada hubungan kebiasaan bermain game online dengan kualitas tidur remaja pada kelas XI di SMKN 1 Seruyan Tengah.

\section{Saran}

Berdasarkan hasil penelitian yang dilakukan peneliti, maka peneliti ajukan saran sebagai berikut :

1. Bagi Siswa

Disarankan agar siswa mengikuti kegiatan ekstrakurikuler SMKN 1 Seruyan Tengah, serta kegiatan aktif di luar sekolah, seperti mengikuti kegiatan kepemudaan, kegiatan keagamaan dan kegiatan gotong royong masyarakat.

2. Bagi Orang Tua

Diharapkan irang tua dapat selalu mengontrol dan memperhatikan aktivitas anaknya agar anaknya mengetahui pentingnya menjaga kualitas tidur bagi remaja dengan mengatur waktu yang dihabiskan untuk bermain game online.

\section{Bagi Guru}

Diharapkan dapat digunakan sebagai bahan atau materi pembinaan kepada siswa tentang kebiasaan bermain game online dan pengaruh menjaga kualitas tidur sehingga dapat memaksimalkan pembelajaran.

4. Bagi Peneliti Selanjutnya

Hasil penelitian ini diharapkan dapat menjadi bahan pembanding yang akan mengkaji hal-hal serupa. Peneliti menyarankan peneliti selanjutnya untuk meneliti pengaruh kebiasaan bermain game online terhadap prestasi akademik.

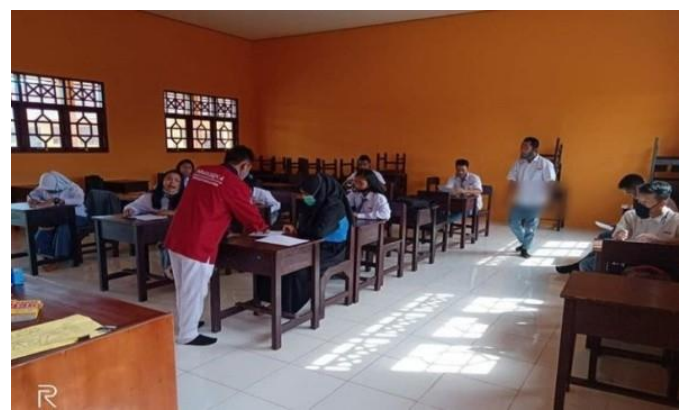

Gambar 1. Pengambillan Uji Validitas Kuesioner di SMKN 1 Seruyan Tengah

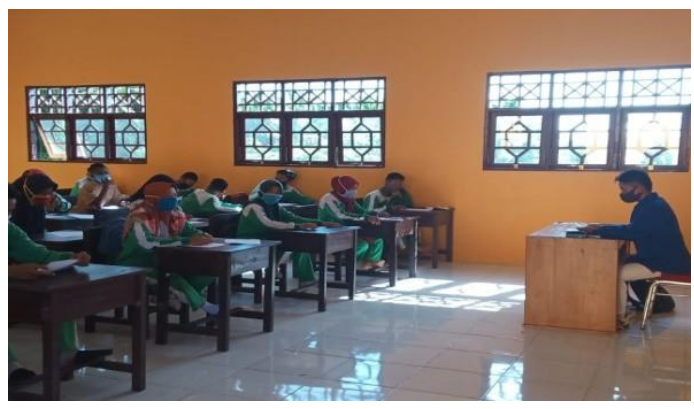

Gambar 2. Pengambillan Data Penelitian di SMKN 1 Seruyan Tengah 


\section{DAFTAR PUSTAKA}

Azizah, L. (2018). Hubungan Kebiasaan Bermain Game Online dengan Kualitas Tidur Remaja Remaja di SMK Dwija Bhakti 2 Jombang.

Astuti, Sri. (2018). Hubungan Kecanduan Bermain Game Online dengan Kualitas Tidur pada Siswa/Siswi Di SMP Negeri 24 Samarinda. Skripsi : Fakultas Ilmu Kesehatan dan Farmasi Universitas Muhamadyah Kalimantan Timur.

Baert, S., Omey, E., \& Verhaest, D. (2015). Bring Me Good Marks On The Relationship Between Sleep Quality and Academic Achivement. Social Science dan Medicine, 130, 91-98.

Fadlilah, M, dkk. (2020). Hubungan Kualitas Tidur dengan Kesiapan Mengikuti Proses Belajar Mahasiswa S1 Keperawatan Semester IV STIKES Muhammadiyah Palembang. Jurnal Ilmu Keperawatan dan Kebidanan. Vol.11 No.1. Hal 86-94.

Fauziawati, Wieke. (2015). Upaya Mereduksi Bermain Game Online Melalui Teknik Diskusi Kelompok. Jurnal Psikopedagogia. Vol. 4, No.2. ISSN: 2301-6167.

Febriana. (2012). Kecanduan Mahasiswa Terhadap Game Online (Studi Tentang Kebiasaan Bermain Game Online di Seturan, Sleman).
eJurnal Sosiologi Volume II, Number 2 Tahun 2012.

Febriandari, D., dkk. (2016). Hubungan Kecanduan Bermain Game Online Terhadap Identitas Diri Remaja. Jurnal Keperawatan Jiwa. Volume 4, No.1. 50-56.

Fithriyana, Rinda. (2019). Hubungan Durasi Bermain Vidio Game Dengan Ketajaman Penglihatan pada Anak Sekolah di SDN 007 Pulau Birandang. Jurnal Ners. Volume 3 Nomor 2 Halaman 11 - 18. Issn : 2580-2194.

Ghozali, Imam. (2011). Aplikasi Analisis Multivariate dengan Program SPSS. Semarang: Badan Penerbit Universitas Diponegoro.

Hidayat. A. A. (2014). Metode Penelitian Keperawatan dan Teknik Analisis Data. Jakarta: Salemba Medika.

Jordan, C. J., \& Andersen, S. L. (2016). Sensitive Periods Of Substance Abuse: Early Risk For The Transition To Dependence. Developmental Cognitive Neuroscience, 25(10), 29-44.

Khasanah. 2012. Kualias Tidur Lansia. Jurnal Nursing Studies. http://repositori.uinalauddin.ac.id/4164/1.pdf. Diakses pada tanggal 23 November 2020.

Kholidiyah, U., \& Yuwono, S. (2013). Hubungan Antara Intensitas Bermain Game Online Dengan Kecerdasan Emosi. Diakses tanggal 08 Desember 2020 dari http://eprints.ums.ac.id. 
Krisna B. P. (2016). Prevalensi Dan Korelasi Insomnia Terhadap Kemampuan Kognitif Remaja Usia 15-18 Tahun di Panti Asuhan Widhya Asih 1 Denpasar. Jurnal: Medika Vol. 5 No. 5. ISSN: 2303-1395.

Kusumawati, Rosi. (2017). Perbedaan Tingkkat Kecanduan (Adiksi) Games Online pada Remaja Ditinjau dari Gaya Pengasuhan. Jurnal RAP UNP. Vol. 8, No. 1. Hal. 88-99.

Notoatmodjo, S. (2010). Metodeologi Penelitian Kesehatan. Jakarta: Rineka.

Notoatmodjo, S. (2014). Ilmu Perilaku Kesehatan. Jakarta: Rineka Cipta.

Nursalam. (2017). Metodeologi Penelitian Ilmu Keperawatan. Jakarta: Salemba Medika.

Ridoi, M. (2015). Cara Mudah Membuat Game Rdukasi Dengan Construct 2.

Rojie. (2016). Hubungan Pengetahuan dan Sikap Orang Tua Tentang Konsep Bermain dengan Tingkat Perkembangan Motorik Anak Usia Pra Sekolah di T/PAUD Alazhiim Lapangan Manado. E-Jurnal Saputra.Oktober 2016 Vol.3 (3).

Saputra, R. A. (2017). Skripsi. Hubungan Kecanduan Bermain Game Online Dengan Kualitas Tidur Pada Remaja Usia 13-16 Tahun Di Warnet Wilayah Kebumen.
Sugiyono. (2018). Metode Penelitian Kuantitatif, Kualitatif dan $R \& D$. Bandung: Alfabeta.

Surbakti, Krista. (2017). Pengaruh Game Online terhadap Remaja. Jurnal Curre. Vol. 01. No. 01. PISSN : 2597-9507. E-ISSN: 2597-9515.

Syahran, Ridwan. (2015). Ketergantungan Online Game dan Penanganannya. Jurnal Psikologi Pendidikan \& Konseling. Volume 1 Nomor 1 Juni 2015. Hal 84-92. ISSN: 2443-2202.

Vollmer, C., Randler, C., Horzum, M. B., \& Ayas, T. (2014). Computer Game Addiction In Adolescents And Its Relationship To Chronotype And Personality. Diakses tanggal 08 Desember 2020. 